\title{
Health Empathy Map: Creation of an Instrument for Empathy Development
}

\section{Mapa da Empatia em Saúde: Elaboração de um Instrumento para o Desenvolvimento da Empatia}

José Maria Peixoto ${ }^{1}$ iD Eliane Perlatto Moura ${ }^{1}$ D

\section{KEYWORDS}

- Medical Education.

- Empathy.

- Physician-Patient Relations.

Introduction: Empathy is a multidimensional construct that requires the ability to perceive and understand the others' perspectives, as well as feel their emotional state. It is an intellectual skill to be learned and represents one of the domains of emotional intelligence. The aim of this study was to create an instrument for the teaching and practice of empathy skills in medical education scenarios, called the "Health Empathy Map" (HEM). Method: This is a qualitative and descriptive study, aimed at developing the Health Empathy Map. The study had 3 phases: (1) Adaptation of the empathy map for medical education scenarios (2) Adequacy of the instrument content performed by teachers from the Outpatient Clinic of José do Rosário Vellano University, during teacher training (3) Assessment of content and feasibility of the instrument, first performed using the focal group technique and then by third-year medical students during outpatient clinic practice and in the tutorial group. Results: The adequacy of the instrument for medical education teaching scenarios was based on conceptual aspects of empathy: perspective-taking, emotional sharing and empathetic concern, as well as suggestions from the outpatient clinic teachers, focal group participants and medical students. All suggestions were debated and accepted, after a consensus that indicated advances and improvements of the instrument, in order to allow its use by students in health learning scenarios. Conclusion: The final version of the HEM was considered by participants of different phases of the study, as an educational instrument with great instructional potential, in terms of stimulating the development of empathy, with a broad use in medical education scenarios. 


\section{PALAVRAS-CHAVE}

- Educação Médica.

- Empatia.

- Relação Médico-Paciente.

\section{RESUMO}

Introdução: A empatia é um construto multidimensional que requer a habilidade de perceber e entender a perspectiva do outro, bem como sentir seu estado emocional. Trata-se de habilidade intelectual a ser aprendida que representa um dos domínios da inteligência emocional. O objetivo deste estudo foi elaborar um instrumento para o ensino e a prática da habilidade de empatia nos cenários de ensino em saúde, denominado Mapa da Empatia em Saúde (MES). Método: Trata-se de um estudo com abordagem qualitativa e descritiva para elaboração do MES. O estudo apresentou três fases: 1. adaptação do Mapa da Empatia a cenários de ensino em saúde, 2. adequação do conteúdo do instrumento realizado por professores de ambulatório da Universidade José do Rosário Vellano (UNIFENAS-BH) durante capacitação docente e 3. avaliação do conteúdo e da exequibilidade do instrumento, primeiramente realizada pela técnica de grupo focal e posteriormente por estudantes do terceiro ano de medicina durante a prática ambulatorial e no grupo tutorial. Resultados: A adequação do instrumento para a utilização em cenários de ensino em saúde foi ancorada nos pilares conceituais da empatia - tomada de perspectiva, compartilhamento emocional e preocupação empática -, bem como nas sugestões dos professores de ambulatório, dos participantes do grupo focal e dos estudantes de medicina. Todas as sugestões foram debatidas e acatadas, após consenso de que indicavam avanços e melhorias do instrumento, no sentido de viabilizar a utilização pelos estudantes em cenários de aprendizagem em saúde. Conclusão: A versão final do MES foi considerada pelos participantes das diferentes fases do estudo uma ferramenta educacional com grande potencial instrucional no que tange ao estímulo do desenvolvimento de empatia, com abrangência de utilização em cenários de ensino na área da saúde.

Received on 10/06/19

Accepted on $11 / 26 / 19$

\section{INTRODUCTION}

Empathy, currently one of the most frequently studied humanistic skills, is the cornerstone of ethical and humanized behavior, an essential element in any humanization strategy ${ }^{1}$. The ability to empathize is associated with greater capacity for problem solving, less impulsiveness, reduced delinquency, group conflicts and stigma ${ }^{2}$.

Empathy is a multidimensional construct and requires the ability to perceive and understand the others' perspective, as well as feel their emotional states. It is an intellectual skill to be learned and represents one of the domains of emotional intelligence ${ }^{3}$. It involves three components: the emotional, the cognitive and the regulation of emotions. The emotional component is based on the sharing and understanding of others' emotional states (mirror neurons), where the actions observed in others are represented internally in the observer's brain ${ }^{4}$. The cognitive component refers to the ability to reason about other people's mental states, and the component regulation of emotions, which depends on the executive function, is responsible for managing and explaining the empathetic response ${ }^{5,6}$. Each one of these components is associated with moral cognition, which comprises three processes: "emotional sharing" (emotional contagion), which is a spontaneous mechanism that occurs through observation and does not depend on the analysis, and another process is the "empathetic concern", which is the motivation to care for vulnerable individuals. Finally, the "perspective-taking" component, associated with competence and social reasoning, which is the capacity to put yourself in someone else's place and imagine what they are thinking or feeling, which is vital for social interactions, as it allows us to understand and predict behaviors. These components of empathy are dissociable, as they use different neural networks ${ }^{7}$. Empathy is related to the emotional response arising from the apprehension or understanding of the emotional state of the other, being an important factor for establishing interpersonal relationships and, therefore, particularly relevant in the doctor-patient relationship ${ }^{8,9}$. Studies have suggested that medical students' empathy may change throughout the course, ranging from a small increase to a decrease in $\mathrm{it}^{10,11,12}$. Interestingly, it has been observed that this skill tends to decrease exactly when medical students start the clinical activity in the undergraduate years ${ }^{13,14,15}$. Authors argue that if empathy can be "lost", it can also be acquired ${ }^{16,9}$. As there is a cognitive side to empathy, it is possible to teach it during the medical training period ${ }^{17}$.

Much has been discussed about methods to teach empathy in care settings, since it is necessary to combine teaching and care at the same time. Some students report difficulties in coordinating the cognitive knowledge necessary for care and still consider the patient's perspective ${ }^{18}$. Model learning, through teacher observation, is efficient, but its applicability is heterogeneous. However, evidence shows that promoting a positive social contact between groups, engaging in practices that encourage consideration of the well-being of others, can change the function and structure of brain regions associated with empathy, suggesting that training can produce changes in the empathy skill, which, like any other skill, improves with practice ${ }^{19}$. The empathy skills can be increased, both in medical and nursing students, when the focus of teaching considers the topic of empathy permeated with care activities ${ }^{18,20}$.

One strategy, used in the business area to stimulate the development of empathy is the use of the Empathy Map, which is a method that helps to design business models according to the client's perspectives by developing a better understanding of the environment, customer's behaviors, aspirations and concerns. The Empathy Map ${ }^{21}$ seeks to facilitate the practice of empathy through a user-centered approach, that is, the focus is on the understanding of the other individual's thinking ${ }^{22}$. The Empathy Map ${ }^{21}$ has 4 quadrants, each containing one of the following words: Say, Think, Do and Feel. The "Say" quadrant will inform what the

REVISTA BRASILEIRA DE EDUCAÇÃO MÉDICA

2 44 (1) : e029; 2020 
user verbalized during the interview, ideally quotes; the "Think" quadrant will show what the user thought during the meeting; the "Do" quadrant will show the actions that the user performs, and the "Feel" quadrant, the emotional state of the user, usually an adjective. Moreover, the Empathy $\mathrm{Map}^{21}$ presents a caricature of the user, placed in the center of the map, named "persona", which is a semi-fictitious representation of the characteristics of the "person" that is related to the business model of a particular activity. The instrument has a visual organization that is easy to apply and guides the analysis from the customers' perspective. Despite being a business plan method, the Empathy Map can be adapted to other purposes ${ }^{21,23}$.

Thus, analyzing the empathy map proposed for the business area, this study aimed to adapt it to the teaching and practice of the empathy skill in health education scenarios. The creation of an objective, structured instrument, which is capable of being used during teaching activities, is necessary, as it will provide the student with an opportunity to think from the patients' perspective, favoring the development of the empathy skill.

\section{METHOD}

This is a study with a qualitative and descriptive approach for the development of the Health Empathy Map.

\section{Instrument development}

The study had 3 phases (Figure 1)

Phase 1: Adaptation of the Empathy Map for use in health education settings

Based on theoretical aspects related to empathy, obtained from literature review and the analysis of the Empathy Map (EM), developed by the XPLANE visual thinking company ${ }^{21}$, an instrument adapted for teaching and practicing empathy skills in outpatient teaching and tutorial group was developed, called the "Health Empathy Map" (HEM).

\section{Phase 2: Adaptation of the instrument's content}

The adaptation of EM content was carried out during a training course on the topic of empathy for outpatient clinic teachers at José do Rosário Vellano University (UNIFENAS-BH). The activity was developed within the Advanced Teacher Development Program in February 2018 and had a 4-hour workload. The training took place in two meetings and had the participation of 40 outpatient teachers from different specialties. In this training, after the presentation of the theoretical aspects of empathy, the HEM was presented to the teachers of the outpatient clinics for content analysis.

\section{Phase 3: Evaluation of the instrument content and feasibility}

The evaluation of the HEM content and feasibility was carried out at two different moments. In the first moment, it was performed through the focal group technique, carried out in February 2019. This technique allows formulating more accurate investigation questions, identifying, in the case of instrument development, what is relevant about the topic and, thus, pointing out the domains that must be covered, promoting insights into how items should be presented (avoiding misunderstandings) and serving as a pre-test of questionnaires and scales ${ }^{24,25,26,27}$. The focal group participants were selected intentionally. Barbour and Kitzinger ${ }^{28}$, recommend that the participants should be selected from a group of individuals who are familiarized with the subject to be discussed and who have a deep knowledge of the factors that affect the most relevant data. The sample consisted of nine participants, and the inclusion criteria consisted of individuals who had knowledge and experience with the topic of empathy, working at different services in the area of health and education, of different age groups and genders, after signing the free and informed consent (FIC) form. The optimal size for a focal group is the one that allows the effective participation of individuals and the appropriate discussion of topics ${ }^{27}$. In the literature, one can observe the use of groups ranging from 6 to 15 participants, and groups with a higher number than that have shown some difficulty in conducting the discussions ${ }^{25}$.

A structured script was used to guide the debate on the topic. The discussion script contained twenty-six questions, of which three were related to semantics; seven questions related to content, two related to pertinence, five related to illustrations, four related to motivation to learn, two related to feasibility, two related to the sequence of responses and one about the need to include another feeling (Chart 1). The free debate among the participants was also carried out and, consequently, questions were asked among them, essential to guarantee the horizontality of the group.

The meeting started with the presentation of the project, explanation about the objectives of the focal group and the work dynamics. After that, the participants were invited to sign the FIC form and to complete a questionnaire including sociodemographic data for the characterization

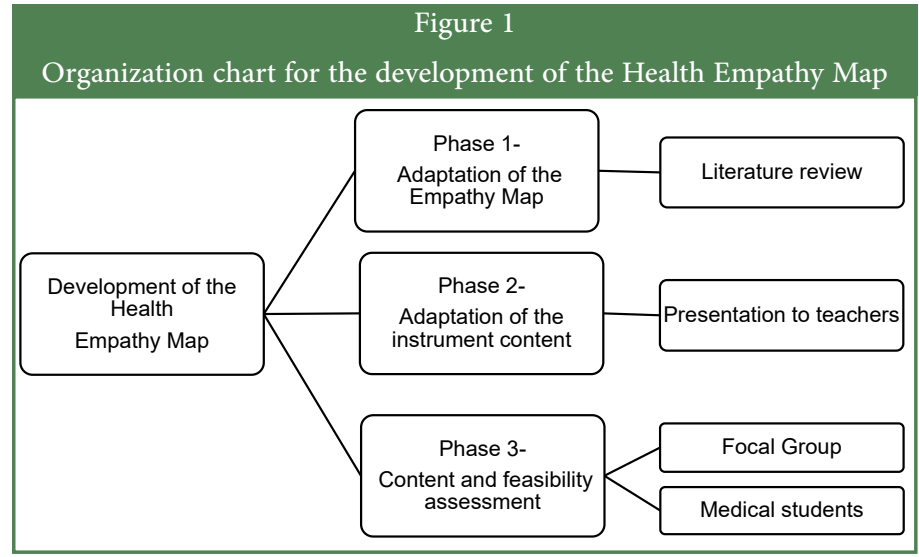

\begin{tabular}{|c|c|}
\hline $\begin{array}{r}\text { Changes in the content of the } \mathrm{H} \\
\text { the te }\end{array}$ & $\begin{array}{l}\text { lth Empathy Map suggested by } \\
\text { hers }\end{array}$ \\
\hline Initial content (version 1$)$ & Final content (version 2) \\
\hline $\begin{array}{l}\text { What do the patients think and feel? } \\
\text { (what is important to them, what are } \\
\text { their concerns and aspirations) }\end{array}$ & $\begin{array}{c}\text { What would you feel if you were in } \\
\text { this person's place? } \\
\text { (perspective taking) }\end{array}$ \\
\hline $\begin{array}{l}\text { What do the patients say or do? } \\
\text { (how the world influences them, } \\
\text { what they believe in and how to } \\
\text { express themselves) }\end{array}$ & $\begin{array}{l}\text { What are this person's needs and } \\
\text { desires? } \\
\text { (current and future ones) }\end{array}$ \\
\hline $\begin{array}{l}\text { What do the patients hear? (how the } \\
\text { world influences them and what they } \\
\text { believe in) }\end{array}$ & $\begin{array}{c}\text { How do I feel about knowing } \\
\text { your story? } \\
\text { (emotional sharing) }\end{array}$ \\
\hline $\begin{array}{l}\text { What do the patients see? (how they } \\
\text { perceive the world, who they believe } \\
\text { in and where they live) }\end{array}$ & $\begin{array}{l}\text { How can I help this person? } \\
\text { (empathetic concern) }\end{array}$ \\
\hline
\end{tabular}

REVISTA BRASILEIRA DE EDUCAÇÃO MÉDICA

3 44 (1) : e029; 2020 
of the work group, containing information on gender, age, profession, time since graduation, work area and degree.

The focal group dynamics occurred in 3 stages, described below:

- Stage 1: Content evaluation: initially a mini class (15 minutes) was given on the concept of empathy, its theoretical foundations and the history of the instrument's development. Then, the guests received the HEM and, individually, performed the assessment of the written content of each item contained in the instrument, aiming to collect the individual opinions without the group influence ${ }^{29}$.

- Stage 2: Discussion of item content and assessment of the pertinence in group: in this phase the moderator coordinated the discussion of the focal group, aiming at collecting the participants' observations and verifying the consensual suggestions regarding the structure and semantic evaluation of the instrument items. The rules of objectivity were followed, with one person speaking at a time, avoiding side conversations and respecting the opinion of others in the group. All suggestions were written down by a rapporteur.

- Stage 3: Feasibility assessment: The participants were invited to watch a video of a medical consultation lasting 4 minutes and, after its end, they individually filled out the HEM, as it will be used in an academic activity, in order to assess the feasibility of the instrument.

At a second moment, the final version of the instrument obtained by the focal group technique, was applied in real learning scenarios during the undergraduate course, in September 2019. The sample consisted of twenty $3^{\text {rd }}$-year medical students, and the inclusion criteria were: being enrolled at UNIFENAS-BH, agreeing to participate in the study and signing the free and informed consent form. The same steps followed in the focal group were performed, and in stage 3 , ten students completed the HEM after analyzing a clinical case in a tutorial group session and ten students after outpatient care, performed by the student in the cardiology outpatient clinic.

Ethical Considerations: The project was sent to the Research Ethics Committee at José do Rosário Vellano University and received a favorable Opinion - CAAE: 02076818.4.0000.5143

\section{RESULTS}

In the first phase of the study, the Empathy Map developed by the XPLANE visual thinking company ${ }^{21}$ was adapted for use in health education settings. In this new instrument, called the "Health Empathy Map", we sought to include the components related to the theoretical and conceptual aspects of empathy obtained in the literature review. The adapted instrument had four quadrants, each containing the following phrases: (1) What the patients say or do (how the world influences them, what they believe in and how they express themselves); (2) what the patients think and feel (what is important to them, what their concerns and aspirations are); (3) What the patients hear (how the world influences them and what they believe in); (4) what the patients see (how they perceive the world, who they believe in and where they live). In the center of the map, instead of the user's caricature, there is an incomplete drawing of an emoji, without the eyebrows and mouth. Like the emojis, they are ideograms that represent emotions; 6 emojis were placed below the map quadrants, representing the 6 facial expressions of universal emotions ${ }^{26}$. As a proposal to apply the instrument in the health education scenario, it was stipulated that, after caring for a patient or analyzing a clinical case in the tutorial group, the students will be instructed to fill in all the map quadrants, demonstrating their own impressions, and finish the drawing of the emoji, in the center of the map, with the facial expression that they believe represents the feeling of the patient they just evaluated. This instrument was presented at an advanced training workshop with outpatient teachers (Phase 2).

In this workshop, after group discussions, the teachers concluded that it was an innovative proposal, but the feasibility of its use in the health education scenario would require an adaptation of terms in order to highlight the empathy components, facilitating its use and student learning. It was suggested to replace the term "patient" by "person", in order to favor the perception of the individual as a person and his/her illness process. Some questions were very subjective and, therefore, difficult to answer (for example: what do the patients hear? How does the world influence them? What are their aspirations?) And it was suggested that they should be replaced by: "How do I feel knowing their history?, how can I help this person?". It was suggested that the conceptual components of empathy should be placed between parentheses, after the phrases in each quadrant, so they would be more evident, favoring the learning and their use by students (perspective-taking, emotional sharing and empathetic concern). After a consensus was reached, the changes suggested by the teachers in the instrument's content were accepted and version 2 of the instrument was achieved (Chart 2). This version was again submitted to content and feasibility analysis, using the focal group technique and, subsequently, in real teaching scenarios (Phase 3).

A three-hour focal group session was planned, in a location with easy access for participants. The session was held in a large room with space for the organization of a coffee breaks and collective discussions, the seats were positioned in a circle, so that the participants, the moderator and the observer shared the same visual field. The group consisted of nine members: four doctors, two nurses; a psychologist; an educator and a medical student (female) aged between 20 and 61 years with a mean of 22 \pm 8.4 years of professional experience in health and education (Table 1), in addition to the moderator and an observer.

Following an operationalization methodological rigor promoted the interactions between the participants and the discussion of the topic of knowledge and common interest. The entire content of the instrument was discussed item by item, respecting the time required for the inquiring of all questions, with an exchange of views among participants on proposed item inclusions and modifications. The opinions were assessed until a consensus was reached.

The participants were unanimous in reporting the need for instructions on how to fill out the instrument at the top of the map, and the need to make it clear in the instructions that the filling out of the HEM refers to the current moment of the consultation, as well as the order to be followed when filling out the questions. This last item was the subject of debates and it was concluded that the filling out order organizes the sequence of analysis of the patient's case, making the student reflect on each of the components of empathy and a logical order of actions: 1) taking the patients' perspective; 2) identifying their needs; 3 ) reflecting on the feelings generated by the encounter; 4 ) consider the actions that need to be taken to solve the identified problems. Therefore, everyone agreed that the quadrants should be numbered. 
Regarding the first quadrant, "What would you feel if you were in this person's place? (perspective taking)" - some participants thought that the question needed to inform that it referred to the moment of the

\begin{tabular}{|c|c|}
\hline \multicolumn{2}{|r|}{$\begin{array}{l}\text { Chart } 2 \\
\text { Script used to guide the focal group discussions }\end{array}$} \\
\hline Questions & Items \\
\hline Semantics & $\begin{array}{l}\text { 1-Clear and intelligible vocabulary } \\
\text { 2-Language accessible to the health student's culture } \\
\text { 3- Learning facilitated by topics }\end{array}$ \\
\hline Content & $\begin{array}{l}\text { 1-Evident purpose } \\
\text { 2-Content focused on purpose } \\
\text { 3-Content highlights the main points } \\
\text { 4- Questions are well individualized } \\
\text { 5-Question related to the perspective-taking meets the } \\
\text { proposed concept } \\
\text { 6-Question related to emotional sharing meets the proposed } \\
\text { concept } \\
\text { 7- Question related to empathetic concern meets the } \\
\text { proposed concept }\end{array}$ \\
\hline Relevance & $\begin{array}{l}\text { 1-Favors the practice of reflection } \\
2 \text {-It is relevant to health education }\end{array}$ \\
\hline Illustrations & $\begin{array}{l}\text { 1-The purpose of the illustrations is clear } \\
\text { 2-Pictures (emojis) are relevant } \\
\text { 3-Legends of the illustrations (emojis) are easy to } \\
\text { understand } \\
\text { 4-The use of the "persona" emojis is relevant to the } \\
\text { purpose of the Map } \\
\text { 5-The legend's emojis correspond to the associated feelings }\end{array}$ \\
\hline $\begin{array}{l}\text { Motivation for } \\
\text { learning }\end{array}$ & $\begin{array}{l}\text { 1-Uses interaction } \\
\text { 2-Guidelines are specific } \\
\text { 3-It is motivating } \\
\text { 4- Good layout }\end{array}$ \\
\hline Feasibility & $\begin{array}{l}\text { 1-Easy to fill in } \\
2 \text {-Easy to be used in health education settings }\end{array}$ \\
\hline $\begin{array}{l}\text { Sequence of } \\
\text { responses }\end{array}$ & $\begin{array}{l}\text { 1-What should be the sequence of responses to the items? } \\
\text { - Would you like to suggest a new sequence for question } \\
\text { presentation? }\end{array}$ \\
\hline
\end{tabular}

Feelings 1- Is it necessary to include any other feelings? evaluation. The suggestion was discussed, and it was concluded that this notion of time would already be indicated in the filling out instructions. It was then decided to maintain the original phrase in the quadrant.

Regarding the second quadrant, "What are this person's needs and desires (current and future)", the question showed a relative degree of difficulty regarding its interpretation and was the subject of intense discussion. It was stated that it was necessary to clarify that the question was related to the "student's perception" about the patient's needs and desires. It was questioned whether the question was related to wishes reported by the patient at the time of the consultation or whether they were latent wishes. Moreover, it was also questioned whether the student would know the difference in meaning between the patient's needs and desires. Another aspect observed by the participants was the lack of information on the empathy domain to which the question is related, present in all other quadrants of the instrument. All were unanimous regarding the inclusion of the empathy domain after the question and the removal of the words "current" and "future" inside the parenthesis. After a debate, there was a consensus that the question should be changed to "What is your perception of this person's needs and desires, current and future ones? (perspective taking).

The analysis of the third quadrant "How do I feel knowing their history" did not raise any discussions in the group. It was only suggested to change "their story" to "this person's story", with the agreement of the whole group.

Regarding the fourth quadrant "How can I help this person" it was observed by some participants that the question was very wide-ranging and could give rise to superficial responses. It was suggested to replace the question by "Do I have anything to offer this person that meets their needs?", but there was no consensus, as some felt that this change did not cover the meaning of the original question. One of the participants was not satisfied with the word "help", but was unable to suggest a better one and, therefore, the majority's decision was to keep the question and make it clear that, in order to facilitate understanding by the students, it should be answered last.

Regarding the design that should be made to complete the emoji expression in the central part of the instrument, there was a great debate. Some suggested that it should be removed and that the students should only choose (by placing an $\mathrm{x}$ ) one of the pictures at the end of

\begin{tabular}{|c|c|c|c|c|c|c|}
\hline \multicolumn{7}{|c|}{ Characterization of the participants in the Focal Group } \\
\hline Participants & Occupation & Gender & Age & Area of practice & Degree & $\begin{array}{l}\text { Experience in } \\
\text { the area (years) }\end{array}$ \\
\hline 1 & Physician & female & 61 & Orthopedics & Specialist & 36 \\
\hline 2 & Physician & male & 44 & Infectious Diseases & $\mathrm{PhD}$ & 20 \\
\hline 3 & Physician & male & 44 & Family and Community Medicine & Specialist & 20 \\
\hline 4 & Physician & male & 41 & Cardiology and Clinical Medicine & Master's degree & 14 \\
\hline 5 & Nurse & female & 53 & Health Service Management & Master's degree & 29 \\
\hline 6 & Nurse & female & 38 & Adult Intensive Care & Specialist & 14 \\
\hline 7 & Educator & female & 54 & Education & Specialist & 29 \\
\hline 8 & Psychologist & female & 45 & Hospital Clinical Psychology & Specialist & 21 \\
\hline 9 & Student & female & 20 & Medicine & Not applicable & 02 \\
\hline
\end{tabular}


the instrument. However, it was argued that the act of drawing activates important brain areas and encourages the student to look at the patient. Thus, it was decided to keep the drawing, but that the students should draw the expression that best exemplified the patient's feeling and, if deemed necessary, he should draw other feelings that arose at the time of the consultation.

The elements of the HEM were adjusted and the consensual contributions were incorporated, so that, at the end of the meeting, the final version of the instrument represented the opinion of $100 \%$ of the group; therefore, there was no need for other meetings. Consequently, version 3 of the instrument was obtained (Figure 2).

At the end of the meeting, this last version was applied to the members of the focal group. The participants were invited to watch a video of a clinical consultation and later were asked to complete the HEM, in order to assess whether it was easy to fill out the instrument and its suitability for use in a clinical care setting. All participants were unanimous in saying that the instrument was easy to fill out and that it stimulated a global view of the reality experienced by the patient, thus being a tool that can be used in health learning scenarios.

At a second moment, the instrument was then applied to $203^{\text {rd }}$-year medical students in two learning contexts: a tutorial group and at outpatient care. The group consisted of twelve women and eight men, ranging in age from 20 to 22 years old. There was consensus by the students regarding the instrument importance for the learning of empathy, as well as the

\section{Health Empathy Map}

Student:

Assisted person (initials):

age:

Gender:

Period:

Instructions: After the consultation, fill out the Health Empathy Map in the presented numerical order. Record your impressions and feelings about this person's current situation

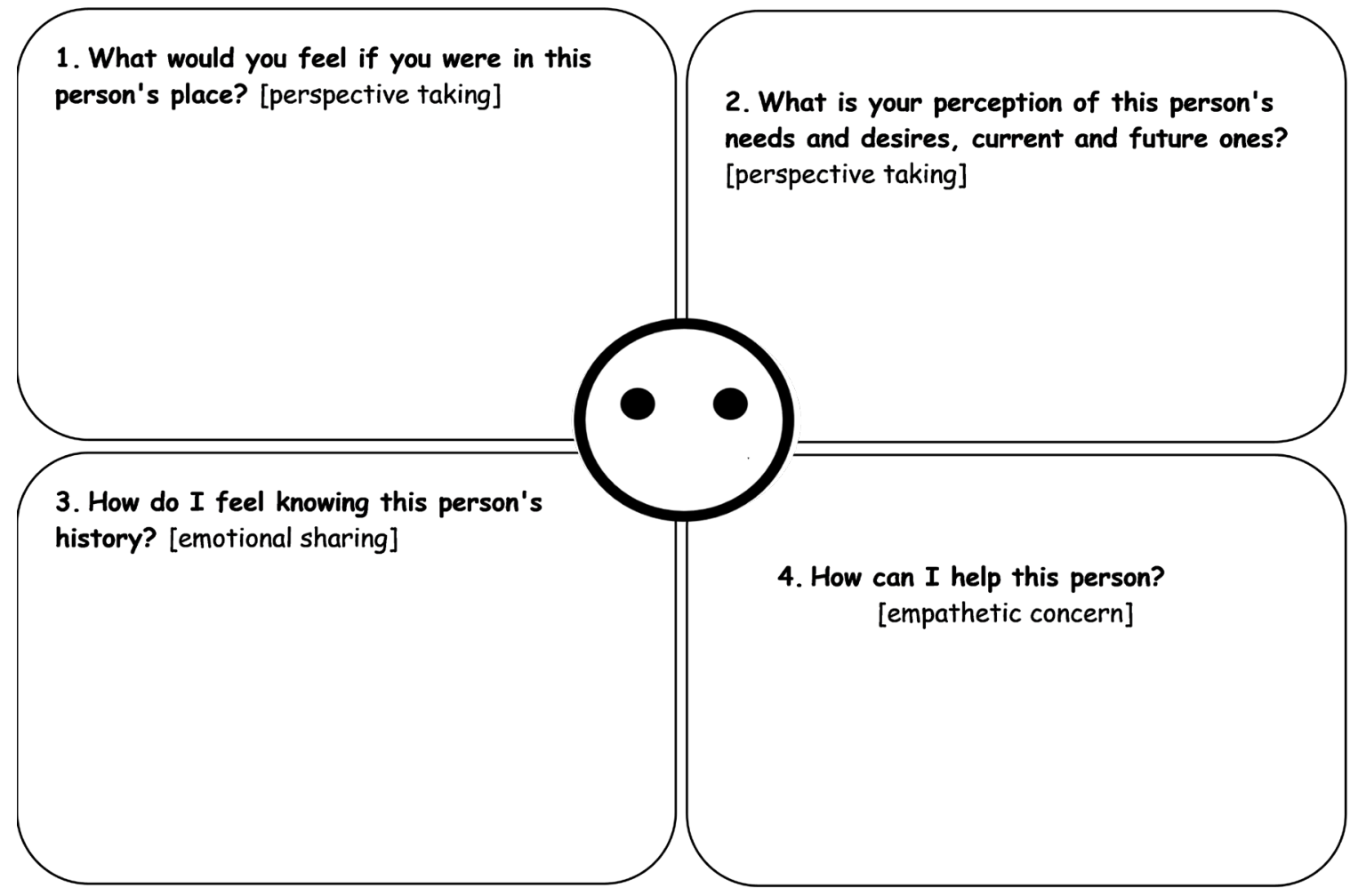

After filling out the instrument, complete the face drawing in the center, in order to demonstrate the image that best expresses the predominant feelings of that person (see examples below). Feel free to mention other feelings:

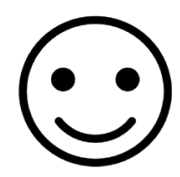

Joy

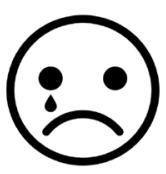

Sadness

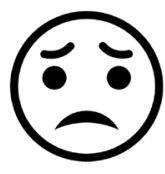

Fear

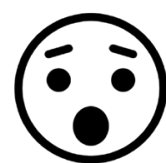

Surprise

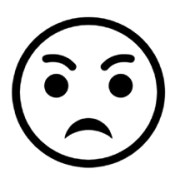

Anger

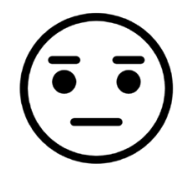

Indifference

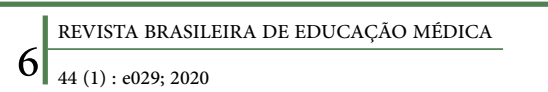


fact that it was easy to understand and fill out. Some students suggested adding more feelings' expressions, such as anxiety, worry and anguish. However, due to the difficulty in obtaining these expressions and to cater to all feelings' expressions, it was decided to maintain the previously chosen expressions, since they represent the 6 expressions of universal emotions, maintaining the phrase: "Feel free to mention other feelings".

At the end of all stages, the final version of the instrument was obtained to be used for the teaching of empathy in health learning scenarios.

\section{FINAL CONSIDERATIONS}

The instrument resulting from this study was considered by the participants as an educational tool with great educational potential, in terms of stimulating the development of empathy in students. We also emphasize the scope of its use, both regarding teaching scenarios, such as: classroom; virtual and real scenarios, and the populations that can use this tool, such as medical students, residents and physicians. New studies should be carried out to evaluate the results of using the instrument, in relation to the development of empathy and the possibility of its use by other health professionals.

\section{ACKNOWLEDGMENTS}

The authors would like to thank all teachers at UNIFENAS-BH who contributed to the development of this study, the students who participated in the initial assessment of the Health Empathy Map during outpatient activities and Tutorial Groups, to the UNIFENASBH Principals (Graduation and Postgraduation) for their support and encouragement received at all stages of the implementation of this project and to the participating members of the focal group for their enormous contribution to the development of this important educational instrument for the health education area.

\section{REFERENCES}

1. Benedetto MAC, Moreto G, Janaudis MA, Levites MR, Blasco PG. Educando as emoções para uma atuação ética: construindo o profissionalismo médico. RBM rev. bras. med. 2014; 71:15-24.

2. Vilardaga R. A Relational Frame Theory account of empathy. International Journal of Behavioral Consultation and Therapy 2009; 5(2):178-84.

3. Paro HBMS. Empatia em estudantes de medicina no Brasil: um estudo multicêntrico. São Paulo. Tese [Doutorado] - Faculdade de Medicina da Universidade de São Paulo; 2013.

4. Riess H, Kraft-Todd G. E.M.P.A.T.H.Y.: a tool to enhance nonverbal communication between clinicians and their patients. Acad. med. 2014; 89:1108-12.

5. Eres R, Molenberghs P. The influence of group membership on the neural correlates involved in empathy. Front. human. neurosci. 2013;7(176):1-6.

6. Chen C, Martínez RM, Cheng Y. The developmental origins of the social brain: empathy, morality, and justice. Frontiers in Psychology 2018; 9:1-9.

7. Decety J, Cowell JM. The complex relation between morality and empathy. Trends cogn. sci. 2014;18(7):337-9.
8. Basílio N, Vitorino ASV, Nunes JM Caracterização da empatia em internos de medicina geral e familiar. Rev. port. med. geral fam. 2017; 33:171-5.

9. Silva HSM Empatia no curso de Medicina e internato médico. Lisboa. Dissertação (Mestrado) - Faculdade de Medicina de Lisboa; 2017.

10. Bombeke K, Van Roosbroeck S, De Winter B, Debaene L, Schol S, Van Hal G et al. Medical students trained in communication skills show a decline in patient-centred attitudes: an observational study comparing two cohorts during clinical clerkships. Patient educ. couns. 2011; 84(3):310-8.

11. Kelly J, Easton G. Geo-sociocultural influences on empathy. Med. educ. 2019;53(7):646-9. doi: 10.1111/medu.13898.

12. Ponnamperuma G, Yeo SP, Samarasekera DD. Is empathy change in medical school geosocioculturally influenced? Med. educ. 2019;53(7):655-65. doi:10.1111/medu.13819.

13. Chen D, Lew R, Hershmam W, Orlander J. A cross-sectional measurement of medical student empathy. J Gen Inters Med 2007; 22:1434-8.

14. Hojat, $M$. The devil is in the third year: a longitudinal study of erosion of empathy in medical school. Acad. med. 2009;84(9):1182-91.

15. Sulzer SH, Feinstein NW, Wendland CL. Assessing empathy development in medical education: a systematic review. Med. educ. 2016;50 (3):300-10.

16. Han JL, Pappas TN. A review of empathy, its importance, and its teaching in surgical training. J. surg. educ. 2018;75(1):88-94.

17. Costa P, Alves R, Neto I, Marvão P, Portela M, Costa MJ. Associations between medical student empathy and personality: a multiinstitutional study. PLos One 2014;9(3):1-7.

18. Mercer SW, Reynolds WJ. Empathy and quality of care. Br. j. gen. pract. 2002;52(suppl):9-12.

19. Marsh AA. The neuroscience of empathy. Current Opinion in Behavioral Sciences 2018; 19:110-5.

20. Schweller M, Costa FO, Antonio MA, Amaral EM, Carvalho-Filho MA de. The impact of simulated medical consultations on the empathy levels of students at one medical school. Acad. med. 2014; 89:632-7.

21. Gray D, Brown S, Macanufo J. Gamestorming. A playbook for innovators, rulebreakers, and changemakers. Massachusetts: O'Reilly Media; 2010.

22. Bratsberg HM. Empathy Maps of the four sight preferences. In: Creative Studies Graduate Student Master's Project. Buffalo State College; 2012. p. 176.

23. Osterwalder A, Pigneur Y. Business model generation: inovação em modelos de negócios. Rio de Janeiro: Alta Books; 2011.

24. Gondim, S.M. Grupos focais como técnica de investigação qualitativa: desafios metodológicos. Paidéia (Ribeirão Preto) 2002;12(24):149-61.

25. Trad LAB. Grupos focais: conceitos, procedimentos e reflexões baseadas em experiências com o uso da técnica em pesquisas de saúde. Physis (Rio J.) 2009;19(3):777-96.

26. Soares $\mathrm{CB}$ et al. Uso de grupo focal como instrumento de avaliação de programa educacional em saúde. Rev. Esc. Enferm. USP 2000;34(3):317-22.

27. Pizzol SJS. Combinação de grupos focais e análise discriminante: um método para tipificação de sistemas de produção agropecuária. Rev.

\begin{tabular}{l|l}
\hline 7 & REVISTA BRASILEIRA DE EDUCAÇÃO MÉDICA \\
\hline 44 (1) : e029; 2020
\end{tabular} 
Econ. Sociol. Rural 2004;42(3):451-68.

28. Barbour RS, Kitzinger J. Developing focus group research. London: Sage; 1999.

29. Veiga L, Gondim SMD. A utilização de métodos qualitativos na ciência política e no marketing político. Opin. pública 2001;7(1):1-15.

\section{AUTHORS' CONTRIBUTION}

José Maria Peixoto and Eliane Perlatto Moura were responsible for the idealization of the Health Empathy Map and actively participated in all stages of this study: research design, data collection, analysis, writing and revision of the manuscript.

\section{CONFLICTS OF INTERESTS}

The authors declare no conflicts of interest.

\section{ADDRESS FOR CORRESPONDENCE}

José Maria Peixoto

Universidade José do Rosário do Rosário Vellano, Rua Líbano, 66 Itapoã, Belo Horizonte, MG-Brasil. CEP: 31710-030

E-mail: jmpeixoto.prof@gmail.com 